\title{
PERADABAN ISLAM DI SPANYOL DAN PENGARUHNYA TERHADAP PERADABAN BARAT
}

\author{
Ubadah \\ STAIN Datokarama Palu, Jl. Diponegoro 23 Palu \\ e-mail: e-mail: ubadah_polman@yahoo.com
}

\begin{abstract}
Spain or Andalusia in the context of classical Islam was one of the provinces of Umayyah Dynasty I or Eastern Amawiyyah. Then it turned into an autonomy dynasty called Daulah Bani Umayyah II or Western Umayyah and separated from Abbasiyyah Dynasty. In the matter of education and science/knowledge development, Western Amawiyyah had been succeeded in competing the brightness of Abbasiyyah Dynasty of Baghdad. Philosophy, science encompassing medicine, surgery, pharmacy, astronomy, mathematics, chemistry, music, etc. were developed at this time. The influence of Islamic sciences on Europe and Western countries had been lasting since $12^{\text {th }}$ A.D century, and brought about the reawakening movement (renaissance) in Europe at $14^{\text {th }}$ A.D century through the Arabic language translations into Latin language.

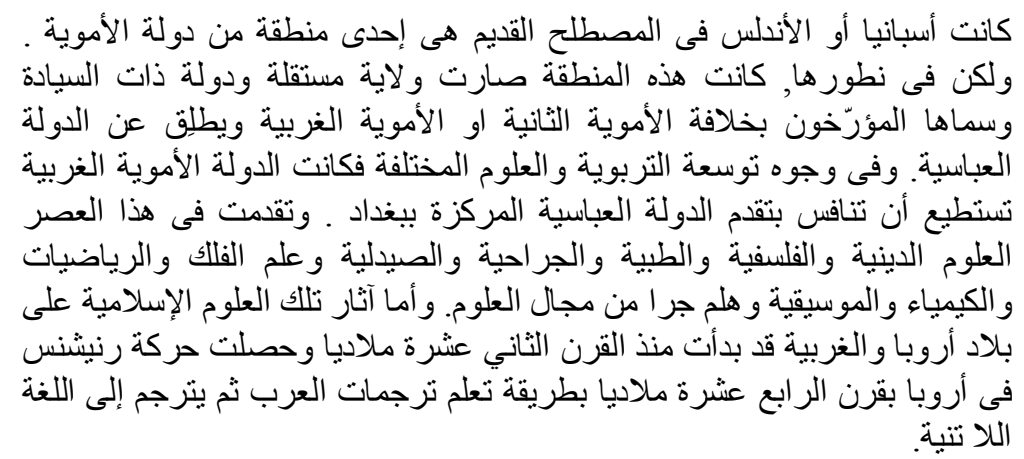

Kata Kunci: peradaban Islam, perdaban Barat, Dinasti Umayyah, Dinasti Abbasiyyah, pendidikan, ilmu pengetahuan 


\section{PENDAHULUAN}

Dalam khazanah Sejarah Peradaban Islam, Dinasti Umayyah (selanjutnya disebut Amawiyyah) dibagi ke dalam dua zona dan periode kekuasaan, Timur (yang berpusat di Damaskus) dan Barat (yang berpusat di Spanyol atau Andalusia). Dalam Enseklopedi Islam (Ridwan, 1994:144) Andalusia adalah sebuah nama yang dikenal di dunia Arab dan Islam untuk semenanjung Iberia. Wilayah itu kini terdiri dari dua Negara, yaitu Spanyol dan Portugal. Sejak Kemenangan Pasukan Islam di bawah kekuasaan Dinasti Amawiyyah I (atau Amawiyyah Timur) dan berhasil merebut serta mengintervensi berbagai kekuatan politik lainnya di Afrika Utara, dengan sendirinya Spanyol telah ikut menyempurnakan keberhasilan mereka. Gubernur Afrika Utara, Mûsâ bin Nusayr mengirim pasukan untuk melakukan penaklukan ke wilayah ini yang dipimpin oleh Panglima Târiq bin Ziyad pada tahun $710 \mathrm{M}$. dan tidak mendapatkan perlawanan yang intensif dari penguasa mereka. Hal ini terjadi karena secara politis pemerintahan pada waktu itu sangat lemah dan tidak mendapat dukungan yang berarti dari rakyat (Shalabî, 1984:123; Hitti, 1970).

Pasukan Târiq bin Ziyad berhasil mengalahkan Raja Roderick dan menewaskannya dalam suatu pertempuran. Kemenangan ini menjadi modal bagi Târiq bin Ziyad dan pasukannya untuk menaklukkan kota lainnya seperti Cordova, Archedonia, Malaga, Elvira, dan akhirnya Toledo, yakni pusat kerajaan Visigoth. Setelah mendengar keberhasilan pasukan Islam, pada tahun $712 \mathrm{M}$. Musa bin Nusair memimpin suatu pasukan menuju Andalusia melalui jalan yang tidak dilalui oleh pasukan Târiq dan berhasil melewati dan menaklukkan pantai barat semenanjung Spanyol yakni Sevilla dan Merida yang kemudian bertemu dengan pasukan $\mathrm{T} \square$ ariq di Toledo. Dengan bergabungnya dua pasukan, daerah yang ditaklukan semakin meluas sampai ke Utara seperti Saragossa, Terrofona, dan Barcelona (Ridwan, !994:144; Shalabî, 1984:129).

Setelah menjadi bagian dari wilayah Islam yang berlangsung dari tahun 711-755 M, wilayah Spanyol diperintah oleh para gubernur yang diangkat langsung oleh pemerintahan pusat Dinasti Amawiyyah yang berada di Damaskus (Syiria). Namun setelah tumbangnya kekuasaan Dinasti Amawiyyah Timur dan berdirinya Dinasti Abbasiyyah, para âmir atau gubernur yang dulu beraviliasi ke 
Damaskus, kini tidak lagi merasa terikat dengan dinasti sebelumnya yang berpusat di Damaskus maupun dinasti yang baru yang dalam hal ini adalah Dinasti Abbasiyyah yang berpusat di Baghdad. Kendati para gubernur itu secara de jure mengakui eksistensi kekhalifahan Abbasiyyah di Baghdad, secara de facto dan politis, mereka tidak mau terikat atau melakukan bay'ah pada pemerintahan baru di Baghdad (Routledge dan Paul dalam Thohir, 2004:59).

Sekalipun Dinasti Amawiyyah telah ditaklukan dan seluruh keturunannya dikejar dan dibunuh, salah seorang dari mereka, 'Abd al-Rahmân bin Mua'wiyyah bin Hishâm bin 'Abd al-Mâlik (yang kemudian bergelar 'Abd al-Rahmân al-Dakhîl yang berarti Sang Penyusup, berhasil meloloskan diri dari pengejaran penguasa Dinasti Abbasiyyah. Dengan dukungan politik dari istana Banî Rustâm di Afrika Utara, 'Abd al-Rahmân al-Dakhîl mulai menyusup memasuki kota Algeciras tahun 755 M. Dalam tahun 756 M., dimulailah masa pengakuan dan bay'ah terhadap eksistensi dan kemenangan al-Dakhîl atas amir-amir di sebagian Spanyol yang meliputi Sevilla, Archidon, Sidonia, dan Moron de Frontura.

Akhirnya, pada tanggal 15 Mei 756 M., 'Abd al-Rahmân alDakhîl memproklamirkan berdirinya Imârah Amawiyyah II di Andalusia. Dengan demikian, secara resmi dimulailah kekuasaan yang kedua dari Dinasti Amawiyyah sebagai Negara yang berdiri sendiri, berdaulat yang lepas dari Abbasiyyah di Baghdad (Sou'ayb, 1977:19; Shalabî, 1984:120-125). Wilayah Islam di Spanyol dalam kekuasaan Amawiyyah II ini, menurut Hitti (1970:162), terbagi ke dalam lima provinsi (vice royalty) yang dikepalai oleh seorang âmir atau $s \square \hat{a h i b}$ dengan Cordova sebagai pusat pemerintahan.

Dengan demikian, Spanyol bukan lagi sebagai sebuah provinsi dari sebuah dinasti, akan tetapi sudah menjadi sebuah Negara yang berdaulat yang mempunyai seorang raja yang lebih menyukai menggunakan gelar Amîr al-Mu'minîn daripada Khalîfah. Sejak saat itu, Spanyol menjadi pusat perdaban Islam di wilayah Eropa yang diperhitungkan oleh negara-negara Eropa dari segi pengaruhnya terhadap peradaban Eropa pada masa itu.

Tulisan ini bermaksud mengkaji pengaruh peradaban Islam yang berpusat di Spanyol dan pengaruhnya terhadap perdaban Barat pada abad pertengahan. 


\section{KEMAJUAN PENDIDIKAN DAN ILMU PENGETAHUAN DI SPANYOL DAN PENGARUHNYA TERHADAP PERADABAN EROPA}

Beberapa sejarawan menyatakan bahwa usaha mengkaji ilmu secara ilmiah di wilayah Barat (Spanyol dan sekitarnya), lebih dulu terjadi di wilayah Timur (Baghdad dan sekitarnya). Dengan demikian, masyarakat intelek muslim yang ada di wilayah Barat berhutang budi kepada saudara-saudara mereka yang berada di Timur (Madkour, 1988: 53).

Cordova, Constantinopel, dan Baghdad adalah tiga kota yang merupakan pusat kebudayaan dunia pada saat itu. Di Cordova terdapat 113.000 rumah, 70 Perpustakaan, sejumlah toko buku dan ratusan mesjid, bermil-mil jalan aspal diterangi dengan lampu-lampu dari rumah-rumah yang berhampiran. Semuanya membuat Cordova memperoleh popularitas internasional dan kekaguman para pengunjungnya. Banyak perutusan diplomatik berkumpul di Cordova, baik dari dalam maupun dari luar Spanyol. Delegasi berdatangan dari suku-suku Zanatah Afrika Utara yang kuat, dari dinasti Idrisiyyah, dari raja-raja Kristen Prancis, Jerman dan Konstantinopel (Hitti, 1970; Shalabî, 1984).

Sehubungan hal di atas, Hitti (1970:526) mengungkapkan:

In this period Umayad Capital took its place as the most cultured city and Europe and, with Constantinople and Baghdad, as one of the three cultural centres of the world. With its one hundred and thirteen thousand homes, twenty-one suburbs, seventy libraries and numerous book shops, mosques and palaces, it acquired international fame and inspired awe and admiration in the hearts of travellers. It enjoy miles of paved streets illuminated by lights from the bordering houses whereas.

Berdasarkan tulisan-tulisan yang ada yang membahas seputar sejarah pendidikan dan sejarah peradaban Islam, secara global, pendidikan Islam di Spanyol terbagi ke dalam dua tingkatan, kuttab dan al-Ma'had al- 'Âlî (semacam Pendidikan Tinggi)

\section{Kuttab}

Dalam konteks kekinian, mungkin lembaga kuttab ini bisa dipadankan dengan lembaga pendidikan pesantren atau minimal halaqah atau pengajian tradisional. Pada lembaga pendidikan kuttab 
ini para siswa mempelajari beberapa bidang studi dan pelajaranpelajaran yang meliputi fikih, bahasa dan sastra, serta musik dan kesenian.

\section{Bidang Fikih}

Dalam bidang fikih, karena Spanyol Islam menganut mazhab Maliki, para ulama memperkenalkan materi-materi fikih dari mazhab Imâm Mâlik. Para ulama yang memperkenalkan mazhab ini antara lain Ziyâd ibn 'Abd al-Rahmân, perkembangan selanjutnya ditentukan oleh Ibn Yahya yang menjadi qâdi pada masa Hishâm ibn 'Abd alRahmân. Ahli-ahli fikih lainnya di antaranya Abû Bakr ibn alQutiyyah, Munzir ibn Saî'd al-Balûti dan Ibn Hazm yang terkenal. (Yatim, 2004:103).

Para siswa di kuttab-kuttab tersebut mendapatkan materi fikih cukup lengkap dari ulama-ulama tersebut yang berkompeten pada disiplin ilmunya. Perkembangan ilmu agama di lingkungan masyarakat intelek Islam Spanyol, oleh sebagian penulis sejarah, didentikkan dengan perkembangan hukum Islam (ilmu fikih) atau ilmu syariat yang telah mengalami penyempitan makna. Namun demikian, dari penyempitan makna tadi, dampak positif yang tampak pada masyarakat adalah adanya suatu tatanan hukum yang pasti dan dipegang sebagai pedoman hidup sehingga aspek-aspek lahiriah sebagai objek kajian ilmu fikih dari masyarakat tersebut, juga tercermin pada sebagian pandangan para filosof, bisa terkendali dan berada dalam landasan-landasan normatif agama (Watt, 1992:61-62).

\section{Bidang Bahasa dan Sastra}

Menurut Hitti (1970:557), di Spanyol sebetulnya (sedikit) tertinggal jika dibandingkan dengan orang-orang Irak namun kemudian prestasi-prestasi yang cukup spektakuler bermunculan. AlQâli (901-67 M.), seorang profesor Universitas Cordova kelahiran Armenia awalnya belajar di Baghdad, baru kemudian disusul oleh Muhammad bin Hasan al-Zubaydî (928-989), seorang muridnya yang berdarah asli Spanyol kelahiran Seville yang mewarnai hampir seluruh ilmu gurunya itu. Sebagai bahasa resmi dan bahasa administrasi dalam pemerintahan Islam di Spanyol, bahasa Arab diajarkan kepada murid-murid dan para pelajar, baik yang muslim maupun yang non muslim. Hal ini dapat diterima oleh masyarakat, bahkan mereka rela 
menomorduakan bahasa asli mereka. Mereka juga banyak yang ahli dan mahir dalam bahasa Arab sehingga mereka terampil dalam berbicara maupun dalam tata bahasa. Di antara ahli bahasa yang terkenal ialah Ibn Mâlik, pengarang kitab Alfiyyah, Ibn Sayyidîn, Ibn Khurûf, Ibn al-Hâjj, Abû 'Alî al-Shiblî, Abû al-Hasan ibn Usfûr, dan Abû Hayyân al-Gharnatî.

Bahkan, Orang Islam Spanyol juga berjasa atas penyusunan tata bahasa Hebrew (bahasa orang Yahudi) yang secara esensial didasarkan pada tata bahasa Arab. Selanjutnya, di bidang sastra, terdapat juga kemajuan yang sangat signifikan dan melahirkan banyak tokoh. Ibn 'Abd al-Rabbih, seorang pujangga yang sezaman dengan 'Abd al-Rahmân III mengarang Al-'Iqd al-Farîd dan Al-Aghânî. 'Alî bin Hazm (terkenal dengan nama Ibn Hazm) juga menulis sebuah antologi syair cinta berjudul Tawq al-Hamâmah. Dalam bidang syair, yang digabungkan dengan dengan nyanyian, terdapat tokoh 'Abd alWahîd bin Zaydân (1003-1071) dan Walladah (w. 1087) yang melakukan improvisasi spektakuler dalam bidang ini. Karya mereka, Muwassah dan Jazal merupakan karya monumental yang pernah mereka ciptakan pada masa itu sehingga orang-orang Kristen mengadopsinya untuk himne-himne Kristiani mereka.

\section{Bidang Musik dan Kesenian}

Syair merupakan ekspresi utama dari peradaban Spanyol. Pada dasarnya, syair Spanyol didasarkan pada model-model syair Arab yang membangkitkan sintimen prajurit dan interes faksional para penakluk Arab (Lapidus, 1999:584). Dalam bidang musik dan seni, Spanyol Islam memiliki tokoh seniman yang sangat terkenal, yaitu al$\mathrm{H} \square$ asan ibn Nâfî dikenal dengan julukan Ziryâb (789-857). Setiap kali ada pertemuan dan perjamuan di Cordova, Ziryâb selalu mempertunjukkan kebolehannya. Ia juga terkenal sebagai penggubah lagu, ilmu yang dimilikinya itu diajarkan kepada anak-anaknya, baik laki-laki maupun perempuan dan juga kepada budak-budak sehingga kemasyhurannya tersebar luas (Shalabî, 1984:128).

\section{Al-Ma'had al-Âlî (Pendidikan Tinggi)}

Masyarakat Arab yang berada di Spanyol merupakan pelopor peradaban dan kebudayaan juga pendidikan, antara pertengahan abad VIII sampai dengan akhir abad XIII. Melalui usaha yang mereka 
lakukan, ilmu pengetahuan kuno dan ilmu pengetahuan Islam dapat ditranmisikan ke Eropa. Bani Umayyah yang berada di bawah kekuasaan Al-Hakam menyelenggarakan pengajaran dan telah memberikan banyak sekali penghargaan kepada para sarjana. Ia telah membangun Universitas Cordova berdampingan dengan mesjid 'Abd al-Rah $\square$ mân III yang selanjutnya tumbuh menjadi lembaga pendidikan yang terkenal di antara jajaran lembaga pendidikan tinggi lainnya di dunia. Universitas ini menandingi dua universitas lainnya, yaitu Al-Azhar di Cairo dan Nizamiyah di Baghdad, dan telah menarik perhatian para pelajar tidak hanya dari Spanyol, tetapi juga dari tempat lain seperti dari negara-negara Eropa, Afrika dan Asia (Alawi, 2000: 16).

Di antara para ulama yang bertugas di Universitas Cordova adalah Ibn Qutaybah yang dikenal sebagai ahli tata bahasa dan Abû 'Alî al-Qâlî yang dikenal sebagai pakar filologi. Universitas ini memiliki perpustakaan yang menampung koleksi sekitar empat juta buku. Universitas ini mencakup jurusan yang meliputi astronomi, matematika, kedokteran, teologi dan hukum. Jumlah muridnya mencapai seribu orang. Selain itu, di Spanyol terdapat Universitas Sevilla, Malaga, dan Granada. Mata kuliah yang diberikan di universitas-universitas tersebut meliputi teologi, hukum Islam, kedokteran, kimia, filsafat, dan astronomi. Sebagai prasasti pada pintu gerbang universitas yang disebutkan terakhir ditulis sebagai berikut:

Dunia ini ditopang oleh empat hal, yaitu pengajaran tentang kebijaksanaan, keadilan dari penguasa, ibadah dari orang-orang yang saleh dan keberanian yang pantang menyerah (Hitti, 1970:135).

\section{Bidang Filsafat}

Atas inisiatif Al-Hakam (961-976 M.), karya-karya ilmiah dan filosofis "diimpor" dari Timur dalam jumlah besar sehingga Cordova dengan perpustakaan dan universitas-universitasnya mampu menyaingi Baghdad sebagai pusat utama ilmu pengetahuan di dunia Islam. Apa yang dilakukan oleh para pemimpin Dinasti Amawiyyah di Spanyol ini merupakan persiapan untuk melahirkan filosof-filosof besar pada masa sesudahnya (Fakhri, 1986:357). Tokoh utama dan pertama dalam sejarah filsafat Arab-Spanyol adalah Abû Bakr Muhammad ibn al-Sayigh yang lebih dikenal dengan Ibn Bâjah. 
Dilahirkan di Zaragoza, ia pindah ke Sevilla dan Granada. Meninggal karena keracunan di Fez tahun 1138 M. dalam usia muda. Seperti AlFarabî dan Ibn Sinâ di Timur, masalah yang dikemukakannya bersifat etis dan eskatologis. Magnum opus-nya adalah Tadbîr alMutawahhidin (Yatim, 2004:101). Tokoh utama kedua adalah Abû Bakr ibn Tufayl, penduduk asli Wadi Asy, sebuah dusun kecil di sebelah Timur Granada dan wafat pada usia lanjut pada tahun $1185 \mathrm{M}$. yang banyak menulis masalah kedokteran, astronomi dan filsafat. Karya filsafatnya yang terkenal adalah Hayy ibn Yaqzân.

Bagian akhir abad XII M. menjadi saksi munculnya seorang pengikut Aristoteles yang terbesar di gelanggang filsafat dalam Islam, yaitu Ibn Rushd dari Cordova, atau lebih dikenal dengan Averroes, ia lahir tahun 1126 M. dan wafat tahun 1198 M. Ciri khasnya adalah kecermatannya dalam menafsirkan naskah-naskah Aristoteles dan kehati-hatiannya dalam menggeluti masalah-masalah klasik tentang keserasian filsafat dan agama. Dia juga ahli fikih dengan karyanya yang termasyhur Bidâyat al-Mujtahîd (Yatim, 2004:101-102) yang sampai kini masih menjadi referensi baik di pesantren maupun di perguruan tinggi Islam.

Jika dilihat perkembangan filsafat di kalangan masyarakat intelek Islam Spanyol, akan tampak dominasi dari tiga orang filosof kelahiran negeri tersebut, yakni: Ibn Bâjah (w. 1138 M.), Ibn Tufayl (w. 1185) dan Ibn Rushd (1126-1198) dengan tidak bermaksud mengecilkan para filosof yang tidak terpopulerkan oleh sejarah, yang telah berjasa meletakkan batu fondasi, membangun dan menyempurnakan filsafat di dataran Andalusia tersebut. Menurut Madkour (1988:54), dua yang pertama dari ketiga filosof ini berada dalam bayang-bayang al-faid-nya Al-Farabî. Ibn Bâjah, dengan Tadbîr al-Mutawahhîd-nya "mengatakan" bahwa manusia bisa berhubungan dengan akal fa'âl dengan perantara ilmu pengetahuan dan pembangunan potensi mereka. Sementara Ibn Tufayl, dengan Hayy bin Yaqz $\square$ an-nya, mengatakan bahwa hanya potensi manusia yang bisa berhubungan dengan akal $f a$ ' $a l$.

\section{Bidang Sains}

Ilmu-ilmu kedokteran, musik, matematika astronomi, kimia dan lain-lain juga berkembang dengan baik. Abbâs ibn Farnas terkenal dalam ilmu kimia dan astronomi. Ia adalah orang pertama yang 
menemukan pembuatan kaca dari batu (Shalabî, 1984:126). Ibrâhîm ibn Yahyâ al-Naqqâs terkenal dalam ilmu astronomi. Ia dapat menentukan waktu terjadinya gerhana matahari dan menentukan beberapa lamanya. Ia juga berhasil membuat teropong yang dapat menentukan jarak antara tata surya dan bintang-bintang. Ahmad ibn Ibas dari Cordova adalah ahli dalam bidang obat-obatan. Umm alHasan ibn Abî Ja'far dan saudara perempuannya al-Hâfiz adalah dua orang ahli kedokteran dari kalangan wanita.

\section{Bidang Kependidikan}

Titik berat ilmu kependidikan yang berkembang pada masyarakat intelek Islam Spanyol adalah perhatian mereka pada keharusan seseorang bisa membaca dan menulis yang secara mendasar ditujukan kepada (kecakapan membaca dan menulis) Aquran, tata bahasa Arab dan syair. Di samping itu, kegiatan kependidikan juga dalam hal-hal tertentu, berpusat pada persoalan-persoalan hukum atau fikih, yang merupakan istilah derivasi tidak langsung dari kata syariat atau wahyu dan mengalami penyempitan makna (Watt, 1992:6). Dalam masyarakat Islam Spanyol, wanita juga memperoleh kedudukan yang tinggi dalam hal penerimaan pendidikan. Suatu keadaan yang, sedikit berbeda dengan kondisi geografis dunia Islam pada umumnya, sangat kontras dengan keadaan umum masyarakat Eropa pada waktu itu.

Dengan kondisi seperti itu, pada abad-abad berikutnya jumlah orang yang belajar ke Spanyol terus bertambah. Universitasuniversitas Cordova, Toledo, Granada, Clan Sevilla dibanjiri para mahasiswa dari bebagai penjuru Eropa, Afrika Utara, Timur dan Tengah. Kondisi seperti itulah yang belakangan dipercayai berjasa mengantar Renaissance dan reformasi ilmu pengetahuan di Eropa.

\section{Bidang Kepustakaan}

Dengan menitikberatkan kepada ilmu pendidikan, masyarakat intelek Islam Spanyol sudah pasti menyediakan sarana-sarana penunjang, agar apa yang mereka lakukan bisa berhasil seoptimal mungkin. Keberadaan perpustakaan dengan sejumlah besar bukunya merupakan salah satu di antara sekian sarana penunjang kependidikan yang menjadi pusat perhatian mereka. Sebagai contoh, perpustakaan 
Al-Hakam yang jumlah bukunya mencapai 400.000 buah (Shalabî, 1992:183). Disamping itu, bursa buku adalah kegiatan yang sering dijumpai di Cordova. Suatu kondisi logis dari sebuah masyarakat intelek yang memusatkan perhatian kepada pengkajian-pengkajian ilmiah.

Sumber-sumber dana yang berasal dari badan-badan wakaf yang didirikan secara khusus untuk itu telah sangat membantu peningkatan kualitas perpustakaan. Managemen Lay Out berkembang seiring perkembangan perpustakaan tersebut, termasuk di dalamnya katalogisasi. Administrasi dan birokrasi peminjaman buku-buku dilaksanakan dengan baik dalam arti adanya ketentuan-ketentuan tertentu bagi peminjam yang terdiri dari dua golongan; yaitu golongan ulama dan non ulama.

\section{Bidang Kesejarahan}

Dalam bidang sejarah dan geografi, wilayah Islam bagian barat melahirkan banyak pemikir terkenal. Ibn Jubayr dari Valencia (11451228 M.) menulis tentang negeri-negeri muslim di Mediterania dan Sicilia. Ibn Batûtah dari Tangier (1304-1377 M.) mencapai Samudera Pasai dan Cina. Ibn al-Khâtib (1317-1374 M.) menyusun riwayat Granada, sedangkan Ibn Khaldun dari Tunis adalah perumus filsafat sejarah. Itulah sebagian nama-nama besar dalam bidang sains (Yatim, 2004:102).

Bahkan dikatakan, perkembangan ilmu kesejarahan di Spanyol tidak bisa lepas dari peran Ibn Khaldun (1332-1406 M.) sebagai sosok reformer, baik analisis sejarah murni ataupun historiografi. Kelahirannya memang agak belakangan dibanding dengan tokohtokoh sejarah Spanyol seperti Ibn Qutaybah (w. 977 M.) dan Ibn Hayyân (988-1076 M.) serta sejarahwan lainnya. Namun demikian, sebuah karya monumentalnya, Muqaddimah, telah mencuatkkan namanya menjadi sosok luar biasa terutama dalam ilmu sejarah. Teori life cycle untuk dinasti-dinasti, baik secara langsung maupun tak langsung telah diadopsi oleh para ilmuwan dunia menjadi teori civilization life cycle. Bahkan Arnold J. Toynbee mengembangkan teorinya dalam buku A Study of History yang sangat mirip dengan teori Ibn Khaldun. 


\section{PENGARUH ILMU PENGETAHUAN ISLAM TERHADAP DUNIA EROPA DAN BARAT}

Spanyol merupakan tempat yang paling utama bagi Eropa menyerap peradaban Islam, baik dalam bentuk hubungan politik dan sosial, maupun perekonomian dan peradaban antarnegara. Orangorang Eropa menyaksikan kenyataan bahwa Spanyol berada di bawah kekuasaan Islam jauh meninggalkan negara-negara tetangganya di Eropa, terutama dalam bidang pemikiran dan sains disamping bangunan fisik. Yang terpenting di antaranya adalah pemikiran Ibn Rushd (1120-1198 M.). Ia melepaskan belenggu taklid dan menganjurkan kebebasan berpikir. Ia mengulas pemikiran Aristoteles dengan cara yang memikat minat semua orang yang berpikiran bebas. Ia mengedepankan sunnatullah menurut pengertian Islam terhadap pantheisme dan anthropomorphisme Kristen. Demikian besar pengaruhnya di Eropa, hingga di Eropa timbul gerakan Averroeisme (Ibn Rushdisme) yang menuntut kebebasan berpikir. Namun Pihak gereja menolak pemikiran rasional yang dibawa gerakan Averroeisme ini.

Berawal dari gerakan Averroeisme inilah, di Eropa kemudian lahir reformasi pada abad ke-16 M. dan rasionalisme pada abad XVII M. Buku-buku Ibn Rushd dicetak di Venesia tahun 1481, 1482, 1483, 1489, dan 1500 M. Bahkan edisi lengkapnya terbit pada tahun 1553 dan 1557 M. Karya-karyanya juga diterbitkan pada abad XVI M. di Napoli, Bologna, Lyonms, dan Strasbourg, dan di awal abad XVII M. di Jenewa.

Pengaruh peradaban Islam, termasuk di dalamnya pemikiran Ibn Rushd, ke Eropa berawal dari banyaknya pemuda-pemuda Kristen Eropa yang belajar di universitas-universitas Islam di Spanyol, seperti Universitas Cordova, Seville, Malaga, Granada, dan Salamanca. Selama belajar di Spanyol, mereka aktif menerjemahkan buku-buku karya ilmuwan-ilmuwan muslim.

Pusat penerjemahan itu adalah Toledo. Setelah pulang ke negerinya, mereka mendirikan sekolah dan universitas yang sama. Universitas di Eropa adalah Universitas Paris yang didirikan pada tahun 1231 M.; tiga puluh tahun setelah wafatnya Ibn Rushd. Di akhir zaman pertengahan Eropa, baru berdiri 18 buah universitas. Di universitas-universitas itu, ilmu yang mereka peroleh dari universitas- 
universitas Islam diajarkan, seperti ilmu kedokteran, ilmu pasti, dan filsafat. Pemikiran filsafat yang paling banyak dipelajari adalah pemikiran Al-Farabî, Ibn Sinâ dan Ibn Rushd.

Dengan kekecualian pada ilmu keagamaan, boleh dikatakan seluruh perkembangan ilmu pengetahuan di masyarakat intelek Islam Spanyol mempengaruhi perkembangan ilmu pengetahuan di dunia Barat, terutama setelah memasuki abad pertengahan. Hal ini relevan dengan pernyataan Chistave Le Bon yang mengatakan bahwa perkenalan dengan peradaban Islamlah sebenarnya yang membawa Eropa menjadi dunia beradab. Abad ke-9 dan ke-10 adalah saat pusatpusat Islam di Spanyol sedang berada di puncak kecemerlangannya. Pusat-pusat intelektual di Barat hanya berupa benteng-benteng yang dihuni oleh para bangsawan yang dirinya merasa bangga atas ketidakmampuan membaca mereka (Ma'arif, 1994:25-26).

Tahap selanjutnya, dengan melalui tahap-tahap kecurigaan ketakutan yang luar biasa dan secara diam-diam kecemburuan dan kekaguman terhadap Islam, masyarakat Eropa akhirnya berhasil mentransfer metodologi ilmiah intelek masyarakat Islam. Ironisnya, masyarakat Islam justru terpuruk dalam fase kemunduran. Metode eksperimen, eksplorasi, observasi, yang pada awalnya digunakan dalam setiap kajian ilmiah, berubah menjadi metode pengulangan pendapat para guru, yang belakangan diketahui bahwa metode tersebut digunakan oleh sedikit masyarakat terpelajar abad pertengahan di Eropa sebelum datangnya Islam (Ma'arif, 1994:34-35).

Sekarang, masyarakat Islam masih sedang berusaha merumuskan jati diri dan peranannya dalam percaturan dunia. Dalam pada itu, tahap-tahap yang pernah dilalui masyarakat Eropa abad pertengahan, sekarang ini tampaknya sedang dilalui masyarakat Islam. Sikap kecurigaan, ketakutan, dan kecemburuan sehingga muncul generalisasi negatif terhadap dunia Barat, sebetulnya menunjukkan kekerdilan intelektual yang tidak perlu lagi ditumbuhsuburkan. Kemajuan umat Islam di bidang sains dan teknologi harus direbutnya kembali dengan banyak belajar dari Barat sebab harus diakui bahwa pemegang kendali perkembangan ilmu pengetahuan dan teknologi dewasa ini berada di tangan para ilmuwan Barat. Namun demikian, tentu saja ilmu pengetahuan dan teknologi yang kita bagun harus senantiasa mempertimbangakan prinsip-prinsip Islam. 


\section{PENUTUP}

Ada dua dinasti besar yang mewarnai sejarah kegemilangan pemerintahan Islam di masa klasik, Bani Umayyah dan Bani Abbasiyyah. Kedua dinasti ini juga berjasa dalam pengembangan peradaban dan ilmu pengetahuan. Khusus Dinasti Umayyah atau Amawiyyah, terbagi dalam dua masa dan wilayah. Umayyah I atau Umayyah Timur berpusat di Damaskus dan Umayyah II atau Umayyah Barat berpusat di Andalusia.

Ketika 'Abd al-Rahmân al-Dakhîl memproklamirkan berdirinya imârah atau kerajaan di Spanyol, dengan sendirinya dia telah mendirikan pemerintahan yang berdiri sejajar dengan pemerintahan Abbasiyyah di Baghdad, meskipun dia tidak menggelari dirinya dengan gelaran khalifah.

Dalam hal ilmu pengetahuan dan peradaban, masuknya Islam di Spanyol merupakan sebuah mixed blessing bagi Eropa dan ternyata memberikan kontribusi yang tak ternilai, baik kepada dunia Islam, terlebih-lebih kepada dunia Barat. Sikap toleransi yang proporsional dalam komposisi masyarakat yang tingkat heterogenitasnya yang cukup tinggi, ternyata telah menghasilkan efek sinergi positif yang luar biasa dalam membangun sebuah nilai peradaban yang plural.

Kemajuan yang dibawa dan diperkenalkan Islam terhadap Dunia Barat ditandai dengan munculnya tokoh-tokoh ilmuwan dan filosouf dari negeri tersebut. Spanyol pulalah yang menjadi gerbang utama masuknya Islam ke dunia Barat dan kemudian membangkitkan Barat dari dunia kegelapan dan mengantakan Eropa pada masa Renaissance serta memperkenalkan mereka pada kemajuan peradaban dan ilmu pengetahuan. Walaupun umat Islam akhirnya terusir dari negeri Spanyol dengan cara yang sangat kejam, ia telah membidani gerakangerakan signifikan di Eropa. Gerakan-gerakan itu adalah renaissance pada abad XIV M. yang bermula di Italia, gerakan reformasi pada abad XVI M., rasionalisme pada abad XVII M., dan pencerahan (aufklaerung) pada abad XVIII M.

\section{DAFTAR PUSTAKA}

Alawi, Ziauddin. 2000. Muslim Education Thought in the Middle Age. Terjemahan oleh Abuddin Nata. Bandung: Angkasa.

Fakhri, Majid. 1986. Sejarah Filsafat Islam. Jakarta: Pustaka Jaya. 
Hitti, Philip K. 1970. History of the Arabs. Edisi ke-10. London: Macmillan. Ma'arif, Syafi'i. 1994. Peta Bumi Intelektualisme Islam di Indonesia. Cet. ke2. Bandung: Mizan.

Lapidus, Ira M. 1999. Sejarah Sosial Umat Islam. Terjemahan oleh Ghufran A. Mashadi. Jakarta: Rajawali Press.

Madkour, lbrahim. 1988. Filsafat Islam Metode dan Penerapannya. Terjemahan oleh Yudian Wahyudi. Jakarta: Rajawali Press.

Ridwan, Kafrawi. (Ed.). 1994. Ensiklopedi Islam. Jakarta: PT. Ichtiar. Baru Van Hoeve.

Thohir, Ajid. 2004. Perkembangan Peradaban di Kawasan Dunia Islam (Melacak Akar-akar Sejarah, Sosial, Politik dan Budaya Umat Islam). Jakarta: RajaGrafindo Persada.

Sou'ayb, Joesoef. 1977. Sejarah Daulah Umayyah II di Cordova. Jakarta: Bulan Bintang.

Shalabî, Ahmad. 1984. Mausu'at al-Târikh al-Islâmî wa al-Hadârat alIslâmiyyah. Kairo: Al-Nahdah al-Mishriyah.

Watt, Montgomery. 1992. A History Islamic Spain. Edinburgh: University Press.

Yatim, Badri. 1997. Sejarah Peradaban Islam (Dirasah Islamiyyah II). Diterbitkan dalam Rangka Kerjasama Lembaga Studi Islam dan Kemasyarakatan (LSIK). Jakarta: PT. RajaGrafindo Persada. 